Research article

\title{
Estrogen receptor and HER2/neu status affect epigenetic differences of tumor-related genes in primary breast tumors
}

\author{
Eiji Sunami ${ }^{1}$, Masaru Shinozaki ${ }^{1}$, Myung-Shin Sim² ${ }^{2}$, Sandy L Nguyen ${ }^{1}$, Anh-Thu Vu', \\ Armando E Giuliano ${ }^{3}$ and Dave SB Hoon ${ }^{1}$
}

\author{
1Department of Molecular Oncology, The John Wayne Cancer Institute, Saint John's Health Center, Santa Monica Blvd, Santa Monica, California \\ 90404, USA \\ 2Department of Biostatistics, The John Wayne Cancer Institute, Saint John's Health Center, Santa Monica Blvd, Santa Monica, California 90404, USA \\ 3Department of Surgical Oncology, The John Wayne Cancer Institute, Saint John's Health Center, Santa Monica Blvd, Santa Monica, California \\ 90404, USA
}

Corresponding author: Dave SB Hoon, hoon@jwci.org

Received: 3 Jan 2008 Revisions requested: 27 Feb 2008 Revisions received: 13 Mar 2008 Accepted: 16 May 2008 Published: 16 May 2008

Breast Cancer Research 2008, 10:R46 (doi:10.1186/bcr2098)

This article is online at: http://breast-cancer-research.com/content/10/3/R46

(C) 2008 Sunami et al.; licensee BioMed Central Ltd.

This is an open access article distributed under the terms of the Creative Commons Attribution License (http://creativecommons.org/licenses/by/2.0), which permits unrestricted use, distribution, and reproduction in any medium, provided the original work is properly cited.

\begin{abstract}
Introduction Estrogen receptor (ER)-positive breast cancers are considered prognostically more favorable than ER-negative tumors, whereas human epidermal growth factor receptor (HER)2/neu-positive breast cancers are associated with worse prognosis. The objective of the present study was to determine whether ER-positive and ER-negative status relates to epigenetic changes in breast cancer-related genes. To evaluate epigenetic differences in tumor-related genes relating to ER and HER2/neu status of primary tumors, we examined the promoter methylation status of the promoter region $\mathrm{CpG}$ islands of eight major breast tumor-related genes (RASSF1A, CCND2, GSPT1, TWIST, APC, NES1, RAR 2 , and CDH1).
\end{abstract}

Methods Paired ER-positive $(n=65)$ and ER-negative $(n=65)$ primary breast tumors $(n=130)$ matched for prognostic factors were assessed. DNA was extracted from paraffin-embedded tumor tissue after microdissection, and methylation-specific PCR and capillary-array electrophoresis analysis were performed.
Results In early stages of tumor progression (T1 and N0), RASSF1A and CCND2 were significantly $(P<0.05)$ more methylated in ER-positive than in ER-negative tumors. GSTP1 hypermethylation was more frequent in the lymph node metastasis positive group than in the negative group. Double negative (ER-negative, HER2/neu-negative) breast cancers had significantly lesser frequencies of RASSF1A, GSTP1, and APC methylation $(P<0.0001, P<0.0001$, and $P=0.0035$, respectively). Both ER and HER2/neu status correlated independently with these epigenetic alterations.

Conclusion We demonstrated significant differences in tumorrelated gene methylation patterns relevant to ER and HER2/neu status of breast tumors. This may be of significance in the assessment of targeted therapy resistance related to ER and HER2/neu status in breast cancer patients.

\section{Introduction}

Hypermethylation is an epigenetic change that blocks the promoter region of a gene and results in gene silencing. In breast cancer, tumor-related genes may be silenced by hypermethylation; many hypermethylated genes have been reported, and silencing of these genes plays important roles in carcinogenesis and tumor progression [1-3]. Identification of epigenetic changes and their correlation with other clinical factors could lead to improvements in cancer diagnosis and treatment.

In patients with breast cancer, estrogen receptor (ER) status is an important treatment and prognostic factor. Breast cancer patients with ER-positive tumors generally have a more favorable prognosis than do those who have ER-negative tumors. These breast cancer patients can be treated successfully with

APC, adenomatous polyposis coli; CCND2, cyclin D2; CDH1, E-cadherin; ER, estrogen receptor; GSTP1, glutathione S-transferase P1; HER2/neu, human epidermal growth factor receptor 2; LN, lymph node; MSP, methylation-specific PCR; NES1, normal epithelial cell-specific 1 or kallikrein 10; RAR 32 , retinoic acid receptor- $\beta 2$; RASSF1A, RAS association domain family 1 A; SLN, sentinel lymph node; TWIST, human basic helix-loop-helix DNA binding protein. 
hormonal therapies such as tamoxifen and aromatase inhibitors [4-9]. Epidemiological studies revealed that patients with ER-positive tumors have risk profiles different from patients with ER-negative tumors. Parity and timing of births were inversely associated with ER-positive tumors, but not with ERnegative tumors, and body mass index after menopause was more strongly associated with ER-positive than with ER-negative tumors [10]. In addition, rates of ER-positive breast cancer incidence have been shown to increase after age 50 to 54 years, whereas the rates of ER-negative breast cancer incidence do not [11].

Similarly, differences in the gene expression patterns of ERpositive and ER-negative tumors have been documented in microarray expression studies, which identified profile differences in breast tumor subtypes [12,13]. These findings suggest that ER status of breast cancer represents distinct phenotypes. However, few studies have determined epigenetic changes in tumor-related genes in relation to ER status in matched-paired breast cancers.

To investigate the epigenetic differences between ER-positive and ER-negative breast cancer, we assessed the methylation frequency of several breast tumor-related genes that are known to undergo hypermethylated changes in breast cancer, and that play important roles in tumorigenesis and cancer progression. The objective of the study was to determine the association between ER status and epigenetic changes in these tumor-related genes.

The genes assessed were as follows: RASSF1A (RAS association domain family 1A; location: 3p21.3; GenBank: AF132675), CCND2 (cyclin D2; location: 12p13; GenBank: AF518005), GSTP1 (glutathione S-transferase P1; location: 11q13; GenBank: U12472), TWIST (human basic helix-loophelix DNA binding protein; location: 7p21.2; GenBank: U80998), APC (adenomatous polyposis coli; location: $5 q 21-$ q22; GenBank: M74088), NES1 (normal epithelial cell-specific 1 or kallikrein 10; location: 19q13.3-q13.4; GenBank: AF024605), RAR $\beta 2$ (retinoic acid receptor- $\beta 2$; location: 3p24; GenBank: X07282), and CDH1 (E-cadherin; GenBank: L08599). RASSF1A is a putative tumor-suppressor gene that is frequently inactivated epigenetically rather than in a mutational event [14]. A direct correlation between promoter region methylation and loss of expression has been shown in many tumor cell lines, including breast cancer [15-18]. RASSF1A can exert a tumor-suppressing effect by blocking oncogenemediated c-Jun amino-terminal kinase activation [19]. It also associates with microtubules and contributes to the maintenance of genomic stability [20]. Loss of CCND2 expression caused by methylation is an early event in breast cancer tumorigenesis [21]. Methylation of CCND2 has been correlated with poor prognosis, implying that CCND2 has a tumor-suppressor function [22]. GSTP1 is one of a family of enzymes that detoxifies hydrophobic electrophiles, and may be part of a protection system from environmental or dietary carcinogens [23]. Our group has previously found that GSTP1 methylation correlates with increased tumor size and increased likelihood of sentinel lymph node metastases [24]. TWIST induces Ecadherin mediated cell-cell adhesion and induction of cell motility. Increased expression of TWIST correlates with tumor invasion and metastasis $[25,26]$. APC gene germline mutations have been shown to be associated with familial adenomatous polyposis. Hypermethylation of the APC promoter is also associated with breast cancer, especially lobular breast cancer [27-29]. NES1 is a putative tumor suppressor gene found to be downregulated in breast cancer [30,31]. $R A R \beta 2$ is postulated to be a tumor suppressor gene. $R A R \beta 2$ methylation correlates with breast cancer metastasis [32]. It is through retinoic acid receptors that retinoids can prevent primary tumor progression [33]. CDH1 expression reduction is regarded as one of the main molecular events involved in dysfunction of the cell-cell adhesion system, triggering cancer invasion and metastasis. Mahler-Araujo and coworkers [34] reported a correlation between negative or reduced $\mathrm{CDH} 1$ expression and lack of ER expression in tumors from 245 breast cancer patients.

This study was conducted to investigate epigenetic differences in specific tumor-related genes between ER-positive and ER-negative breast cancers. We hypothesized that ERpositive breast tumors have different epigenetic profiles of tumor-related genes during early stages of cancer progression. We examined the methylation status of eight genes suspected of being involved in regulation of breast cancer, and investigated the methylation status of those genes at different stages of tumor development. We compared the methylation status of these genes between ER-positive and ER-negative breast tumors in early and advanced stages to investigate whether epigenetic changes occur in early stages of primary tumor progression.

Human epidermal growth factor receptor (HER) $2 /$ neu is an important factor for treatment and prognosis. HER2/neu overexpression occurs in $15 \%$ to $25 \%$ of breast tumors and is associated with poor prognosis and resistance to hormonal therapy [35-37]. HER2/neu and ER expression have been reported to exhibit an inverse correlation [9,38,39]. Furthermore, previous reports have demonstrated the effect of estrogen on downregulation of HER2/neu production [40]. We investigated the epigenetic differences between HER2/neupositive and HER2/neu-negative breast tumors relative to ER status and further identified the epigenetic characteristics of ER-negative, HER2/neu-negative (double-negative) breast tumors.

\section{Materials and methods Tumor and patient selection}

Sixty-five paraffin-embedded, invasive ER-negative and ERpositive breast tumor pairs were matched for patient age, 
tumor size (T stage), nodal status (lymph node [LN] metastasis positive or negative), and presence or absence of distant metastases ( $\mathrm{M}$ status). The primary tumor characteristics are listed in Tables 1 and 2. HER2/neu status was originally scored 0 to $3+$, and 0 and $1+$ tumors were regarded as HER2/neu negative. Tumors were graded and staged according to the American Joint Committee on Cancer 6th Edition Guidelines [41]. Informed consent for use of all human specimens in this study was obtained under a protocol approved by Saint John's Health Center (Santa Monica, CA, USA)/John Wayne Cancer Institute institutional review board.

\section{DNA processing and methylation-specific PCR}

DNA was extracted as previously described [24]. Briefly, paraffin-embedded primary tumor specimen blocks were sectioned at $10 \mu \mathrm{m}$ and deparaffinized in 100\% xylene, followed by a $100 \%$ ethanol incubation, and stained with hematoxylin and eosin. Tumor tissue was microdissected in comparison with a similarly stained and cover-slipped reference slide cut

Table 1

\begin{tabular}{|c|c|c|}
\hline Clinical factors & ER negative $(n=65)$ & ER positive $(n=65)$ \\
\hline \multicolumn{3}{|l|}{ Menopausal status } \\
\hline Premenopause & 35 & 35 \\
\hline Postmenopause & 30 & 30 \\
\hline \multicolumn{3}{|l|}{ T stage } \\
\hline $\mathrm{T} 1 \mathrm{c}$ & 24 & 24 \\
\hline $\mathrm{T} 2$ & 37 & 37 \\
\hline ТЗ & 4 & 4 \\
\hline \multicolumn{3}{|l|}{$\mathrm{N}$ stage } \\
\hline No & 38 & 38 \\
\hline N1 & 26 & 27 \\
\hline N2 & 1 & 0 \\
\hline \multicolumn{3}{|l|}{ M stage } \\
\hline Mo & 65 & 65 \\
\hline M1 & 0 & 0 \\
\hline \multicolumn{3}{|l|}{ AJCC stage } \\
\hline I & 17 & 17 \\
\hline Ila & 28 & 28 \\
\hline llb & 16 & 16 \\
\hline Illa & 4 & 4 \\
\hline IV & 0 & 0 \\
\hline HER2/neu & $14 / 51(27 \%)$ & $15 / 56(27 \%)$ \\
\hline Total & 65 & 65 \\
\hline
\end{tabular}

ER, estrogen receptor; HER, human epidermal growth factor receptor. from each tissue block. DNA preparation buffer containing 50 $\mathrm{mmol} / \mathrm{l}$ Tris, $1 \mathrm{mmol} / /$ EDTA, 2.5\% Tween-20, and Proteinase $\mathrm{K}$ (QIAGEN, Valencia, CA, USA) was added to microdissected tissue and incubated at $50^{\circ} \mathrm{C}$ overnight. DNA was extracted from the aqueous layer using phenol-chloroform-isoamyl alcohol (25:24:1; Fisher Scientific, Pittsburgh, PA, USA) and precipitated using pellet paint NF co-precipitant (Novagen, Madison, WI, USA). DNA was resuspended in molecular biology grade $\mathrm{H}_{2} \mathrm{O}$ (Fisher Scientific). DNA quantification was performed on all specimens using the PicoGreen quantification assay (Molecular Probes, Eugene, OR, USA). Bisulfite modification was performed as previously described $[15,24]$. A panel of eight genes was assessed for methylation status: RASSF1A, APC, TWIST, CDH1, GSTP1, NES1, CCND2, and $R A R \beta 2$. Methylation-specific PCR (MSP) was performed using AmpliTaq Gold DNA polymerase (Perkin Elmer, Norwalk, CT, USA) and 50 pmol each of forward and reverse primers for methylated (M) and unmethylated (U) sequences. Primer sequences for MSP of the eight genes are shown in Table 3.

PCR was carried out after optimizing annealing temperatures for each primer set to include 40 timed cycles of denaturation at $94^{\circ} \mathrm{C}$ for 30 seconds, annealing for 30 seconds, and extension at $72^{\circ} \mathrm{C}$ for 30 seconds. Post-MSP product analysis was performed using capillary array electrophoresis (CEQ 8000XL, Beckman Coulter, Fullerton, CA, USA), as described previously $[15,24]$.

\section{Statistical analysis}

Descriptive statistics were used to summarize patient characteristics and gene hypermethylation status. $\chi^{2}$ test and Fisher's exact test were used to compare methylation status between ER-positive and ER-negative subgroups, and to compare those differences according to clinical factors, such as tumor size ( $\mathrm{T}$ stage) and nodal status ( $\mathrm{N}$ stage). All statistical analyses were carried out using the SAS system (SAS, Cary, NC, USA), and $P<0.05$ was considered statistically significant.

\section{Results Methylation status of genes in ER-negative and ER- positive tumors}

Initially, the difference in methylation status of eight genes between the age-matched and tumor background-matched ER-negative and ER-positive groups was analyzed using $\chi^{2}$ tests. A representative example of methylated and unmethylated gene analysis from paraffin-embedded tissue is shown in Figure 1. For RASSF1A, CCND2, GSTP1, TWIST, and APC genes, the proportion of methylated genes was significantly higher in the ER-positive than in the ER-negative tumor group. However, no significant differences in methylation status were detected in NES1, RAR 32 , and $C D H 1$. Among the eight biomarkers studied, none exhibited predominance of methylation status in ER-negative tumors by univariate analysis (Table 
Table 2

\begin{tabular}{llll}
\hline Clinical factors by HER2/neu status & & \\
\hline Clinical factors & HER2/neu negative & HER2/neu positive & $P$ value $^{\mathrm{a}}$ \\
\hline T stage & 29 & 10 & $\mathrm{NS}$ \\
T1 & 49 & 16 & 15 \\
T2/3 & 50 & 14 & $\mathrm{NS}$ \\
N stage & 28 & $50.8 \pm 12.6$ & $\mathrm{NS}$ \\
N0 & $50.2 \pm 11.3$ & & \\
N1 & & & \\
\hline
\end{tabular}

${ }^{a} \chi^{2}$ test and Student's $t$-test. HER, human epidermal growth factor receptor; NS, not significant.

4). Based on this finding, we conducted further analysis of the methylation status of RASSF1A, CCND2, GSTP1, TWIST, and $A P C$. Second, we analyzed the differences in the methylation status of these five tumor-related genes between premenopausal and postmenopausal, T1 and T2/T3, and LN metastasis negative (N0) and positive (N1/N2) subgroups using univariate analysis. Among these five genes, there were no significant differences in methylation frequency between premenopausal and postmenopausal subgroups and T1 and T2/T3 subgroups. Only GSTP1 exhibited significantly more frequent methylation in the N1/N2 subgroup than in the N0 subgroup (Tables 5 to 7 ).

\section{Methylation status of genes in ER-negative and ER- positive early-stage tumors}

To study further the changes in tumor-related gene methylation status of both ER-positive and ER-negative breast cancers during tumor progression, we investigated the difference between both ER-positive and ER-negative primary tumors based on American Joint Committee on Cancer T and $\mathrm{N}$ stages. First, we compared the methylation status of five different genes in ER-negative and ER-positive tumors for T1c and T2/T3 stages (Table 8). The ER-positive group exhibited more frequent methylation of RASSF1A and CCND2 in both T1c and T2/T3 stages. GSTP1 and TWIST were more methylated in the ER-positive group in the T1c stage, but the differences did not achieve statistical significance. However, they showed significant differences in T2/T3 stage. We examined changes in the methylation frequency ratio (methylation frequency of gene in the ER-positive group/methylation frequency of gene in the ER-negative group) for each tumorrelated gene during tumor progression. No difference in the methylation frequency ratio was observed between $\mathrm{T} 1 \mathrm{c}$ and T2/T3 stages for all tumor-related genes assessed.

Next, we investigated the difference in methylation of tumorrelated genes between the ER-negative and ER-positive subgroups of NO and N1/N2 tumors (Table 9). The ER-positive group exhibited significantly $(P<0.05)$ more frequent methylation of RASSF1A, CCND2, and GSTP1 in both N0 and N1/
N2 stages. TWIST and APC were more frequently methylated in the ER-positive group in the NO stage, but not significantly. Similar to subgroups divided by $\mathrm{T}$ stage, there were no differences in methylation frequency ratio for all genes assessed between the $\mathrm{NO}$ and N1/N2 subgroups.

\section{Methylation status of tumor-related genes relevant to HER2/neu status}

In addition to ER, we investigated differences in methylation status of the eight genes between the HER2/neu-negative and HER2/neu-positive tumor groups. First, we analyzed the relation between ER status and HER2/neu status. Using matched samples, no difference was found in the frequency of HER2/ neu-positive tumors between the ER-negative and ER-positive groups. Then, the differences in methylation status of all eight genes were analyzed between the HER2/neu-positive and HER2/neu-negative tumor groups. The proportion of methylated RASSF1A, GSTP1, and APC genes was significantly greater in the HER2/neu-positive than in the HER2/neu-negative tumor group; no significant differences in methylation status were detected for TWIST, NES1, RAR 32 , and CCND2. Among the eight biomarkers studied, $\mathrm{CDH} 1$ showed predominance of methylation status in HER2/neu-negative tumors by univariate analysis (Table 10). Next, we compared the methylation status of double-negative tumors versus breast cancers expressing either ER or HER2/neu. The double-negative breast cancer group showed less frequent methylation of APC, GSTP1, RASSF1A, and TWIST (Table 11). Logistic regression analysis revealed that both $\mathrm{ER}$ and $\mathrm{HER} 2 /$ neu status affect the methylation status of APC, GSTP1, and RASSF1A independently.

\section{Relation between the tumor-related genes with respect to methylation status}

The relation between the genes with respect to methylation status is shown in Table 12. GSTP1 methylation frequency is significantly related to methylation frequency of other genes. RASSF1A and TWIST methylation frequencies were significantly related to methylation frequency of three of four other genes. CCND2 and APC methylation frequency related with 
Table 3

\begin{tabular}{|c|c|c|c|}
\hline Gene & Methylated/unmethylated & Direction & Sequence \\
\hline \multirow[t]{4}{*}{ RASSF1A } & Methylated & Forward & 5'-GTGTTAACGCGTTGCGTATC-3' \\
\hline & & Reverse & 5'-AACCCCGCGAACTAAAAACGA-3' \\
\hline & Unmethylated & Forward & 5'-TTTGGTTGGAGTGTGTTAATGTG-3' \\
\hline & & Reverse & 5'-CAAACCCCACAAACTAAAAACAA-3' \\
\hline \multirow[t]{4}{*}{ CCND2 } & Methylated & Forward & 5'-TACGTGTTAGGGTCGATCG-3' \\
\hline & & Reverse & 5'-CGAAAACATAAAACCTCCACG-3' \\
\hline & Unmethylated & Forward & 5'-GTTATGTTATGTTTGTTGTATG-3' \\
\hline & & Reverse & 5'-TAAAATCCACCAACACAATCA-3' \\
\hline \multirow[t]{4}{*}{ GSTP1 } & Methylated & Forward & 5'-TTCGGGGTGTAGCGGTCGTC-3' \\
\hline & & Reverse & 5'-GCCCCAATACTAAATCACGACG-3' \\
\hline & Unmethylated & Forward & 5'-GATGTTTGGGGTGTAGTGGTTGTT-3' \\
\hline & & Reverse & 5'-CCACCCCAATACTAAATCACAACA-3' \\
\hline \multirow[t]{4}{*}{$A P C$} & Methylated & Forward & 5'-TATTGCGGAGTGCGGGTC-3' \\
\hline & & Reverse & 5'-TCGACGAACTCCCGACGA-3' \\
\hline & Unmethylated & Forward & 5'-GTGTTTTATTGTGGAGTGTGGGTT-3' \\
\hline & & Reverse & 5'-CCAATCACAAACTCCCAACAA-3' \\
\hline \multirow[t]{4}{*}{ TWIST } & Methylated & Forward & 5'-TTTCGGATGGGGTTGTTATCG-3' \\
\hline & & Reverse & 5'-GACGAACGCGAAACGATTTC-3' \\
\hline & Unmethylated & Forward & 5'-TTGGATGGGGTTGTTAATTGT-3' \\
\hline & & Reverse & 5'-АССТТССТССАACAAACACA-3' \\
\hline \multirow[t]{4}{*}{ NES1 } & Methylated & Forward & 5'-TTCGAAGTTTATGGCGTTTC-3' \\
\hline & & Reverse & 5'-TTATTTCCGCAATACGCGAC-3' \\
\hline & Unmethylated & Forward & 5'-TTGTAGAGGTGGTGTTGTTT-3' \\
\hline & & Reverse & 5'-CACACAATAAAACAAAAAACCA-3' \\
\hline \multirow[t]{4}{*}{$R A R \beta 2$} & Methylated & Forward & 5'-GAACGCGAGCGATTCGAGT-3' \\
\hline & & Reverse & 5'-GACCAATCCAACCGAAACG-3' \\
\hline & Unmethylated & Forward & 5'-GGATTGGGATGTTGAGAATGT-3' \\
\hline & & Reverse & 5'-CAACCAATCCAACCAAAACAA-3' \\
\hline \multirow[t]{4}{*}{$\mathrm{CDH} 1$} & Methylated & Forward & 5'-TTAGGTTAGAGGGTTATCGCGT-3' \\
\hline & & Reverse & 5'-TAACTAAAAATTCACCTACCGAC-3' \\
\hline & Unmethylated & Forward & 5'-TAATTTTAGGTTAGAGGGTTATTGT-3' \\
\hline & & Reverse & 5'-CACAACCAATCAACAAC ACA-3' \\
\hline
\end{tabular}

MSP, methylation-specific PCR.

two of four other genes. In total, we examined 10 different relationships among five genes; seven of the 10 correlations $(70 \%)$ were statistically significant $(P<0.05)$.

\section{Discussion}

During the past several years, new molecular biomarkers have been discovered that are important targets for the diagnosis and therapy of breast cancer [3,42]. ER and HER2/neu are important prognostic biomarkers and therapeutic targets in primary breast cancer. ER-negative tumors appear to be more malignant $[4,7,8,43]$, resulting in a poorer prognosis than with ER-positive tumors $[5,9,44]$. The present study was conducted to identify differences in epigenetic events related to ER expression by infiltrating breast cancer. To date, few stud- 
Table 4

Comparison of primary tumor gene methylation status relative to ER status

\begin{tabular}{llllll}
\hline \multirow{2}{*}{ Gene } & \multicolumn{2}{c}{ ER negative $(n=65)$} & \multicolumn{2}{c}{ ER positive $(n=65)$} & \multirow{2}{*}{$P$ value $^{\mathrm{a}}$} \\
\cline { 2 - 5 } & $n$ & $\%$ & $n$ & $\%$ & \\
\hline RASSF1A & 36 & $55 \%$ & 60 & $92 \%$ & $<0.0001$ \\
CCND2 & 26 & $40 \%$ & 45 & $69 \%$ & 0.0008 \\
GSTP1 & 4 & $6 \%$ & 19 & $29 \%$ & 0.0006 \\
TWIST & 17 & $26 \%$ & 32 & $49 \%$ & 0.0066 \\
APC & 20 & $31 \%$ & 31 & $48 \%$ & 0.048 \\
NES1 & 13 & $20 \%$ & 22 & $34 \%$ & NS \\
RAR 22 & 18 & $28 \%$ & 17 & $26 \%$ & NS \\
CDH1 & 53 & $82 \%$ & 54 & $83 \%$ & NS \\
\hline
\end{tabular}

${ }^{a} \chi^{2}$ test or Fisher's exact test was used appropriately. ER, estrogen receptor; NS, not significant.

ies have rigorously assessed matched paired ER-negative and ER-positive primary breast tumors for epigenetic differences. We focused on the epigenetic differences between ER-positive and ER-negative breast cancers, and used tumor specimen pairs matched for patient age, size, nodal status, and presence or absence of distant metastases. This sampling enabled rigorous analysis, and the results imply that epigenetic features of ER-positive tumors are different from those of ER-negative tumors.

Widschwendter and coworkers [3] demonstrated that methylation of APC correlated with ER positivity. Our data are consistent with this previous report. Furthermore, we demonstrated a significant difference in methylation status of RASSF1A, CCND2, GSTP1, TWIST, and APC between the ER-positive and ER-negative groups. In contrast, Li and colleagues [45] reported that ER-positive patients exhibited a higher frequency of TWIST methylation and a lower frequency of $\mathrm{CDH} 1$ methylation than did ER-negative patients. They also found no significant differences in the methylation frequencies
Table 6

Comparison of primary tumor gene methylation status relative to $T$ stage

\begin{tabular}{llllcl}
\hline \multirow{2}{*}{ Gene } & \multicolumn{2}{l}{$\mathrm{T} 1(n=48)$} & \multicolumn{2}{l}{ T2/T3 $(n=82)$} & \multirow{2}{*}{$P$ value $^{\mathrm{a}}$} \\
\cline { 2 - 4 } & $n$ & $\%$ & $n$ & $\%$ & \\
\hline RASSF1A & 34 & $71 \%$ & 62 & $77 \%$ & $\mathrm{NS}$ \\
CCND2 & 30 & $63 \%$ & 41 & $50 \%$ & $\mathrm{NS}$ \\
GSTP1 & 9 & $19 \%$ & 14 & $17 \%$ & $\mathrm{NS}$ \\
TWIST & 18 & $38 \%$ & 31 & $38 \%$ & $\mathrm{NS}$ \\
APC & 17 & $35 \%$ & 34 & $41 \%$ & $\mathrm{NS}$ \\
\hline
\end{tabular}

a $\chi^{2}$ test. NS, not significant.

of $R A R \beta 2, C C N D 2$, and $C D H 1$ between ER-positive and ERnegative groups. The reason for the dissimilarity in study findings may be due to differences in methylation analysis; $\mathrm{Li}$ and colleagues assessed methylated PCR products by gel electrophoresis, which is more subjective and less sensitive than capillary array electrophoresis analysis of methylated PCR products. The discrepancy may also have resulted from differences in the approach to the particular specimens assessed. Because methylation and ER status change with tumor progression [25], care should be taken when sampling ER-positive and ER-negative tumors to evaluate epigenetic changes and clinical associations.

To clarify when differences in methylation status between ERpositive and -negative tumors occur, we compared differences in methylation status between T1c and T2 stage subgroups. The ER-positive group exhibited significantly more frequent hypermethylation of two genes (RASSF1A and CCND2), independent of $\mathrm{T}$ stage. Moreover, the ratio of methylation frequency does not differ between T1c and T2/T3 stage subgroups. This observation indicates that the differences in methylation patterns do not significantly change when breast tumors progress from T1c to T2/T3 stage. Similarly, no difference in the methylation frequency ratio was detected between

Table 5

Comparison of primary tumor gene methylation status relative to patient menopausal status

\begin{tabular}{llllll}
\hline Gene & \multicolumn{2}{c}{ Premenopause $(n=70)$} & \multicolumn{2}{c}{ Postmenopause $(n=60)$} & $P$ value \\
\cline { 2 - 5 } & $n$ & $\%$ & $n$ & $\%$ & NS \\
\hline RASSF1A & 52 & $74 \%$ & 44 & $73 \%$ & NS \\
CCND2 & 40 & $57 \%$ & 31 & $52 \%$ & NS \\
GSTP1 & 13 & $19 \%$ & 10 & $17 \%$ & NS \\
TWIST & 25 & $36 \%$ & 24 & $40 \%$ & NS
\end{tabular}

${ }^{\mathrm{a}} \chi^{2}$ test. NS, not significant. 
Table 7

\begin{tabular}{|c|c|c|c|c|c|}
\hline \multirow[t]{2}{*}{ Gene } & \multicolumn{2}{|c|}{ No $(n=76)$} & \multicolumn{2}{|c|}{$\mathrm{N} 1 / \mathrm{N} 2(n=54)$} & \multirow[t]{2}{*}{$P$ value ${ }^{a}$} \\
\hline & $n$ & $\%$ & $n$ & $\%$ & \\
\hline RASSF1A & 54 & $71 \%$ & 42 & $78 \%$ & NS \\
\hline CCND2 & 42 & $55 \%$ & 29 & $54 \%$ & NS \\
\hline GSTP1 & 8 & $11 \%$ & 15 & $28 \%$ & 0.011 \\
\hline TWIST & 28 & $37 \%$ & 21 & $39 \%$ & NS \\
\hline$A P C$ & 30 & $39 \%$ & 21 & $39 \%$ & NS \\
\hline
\end{tabular}

a $\chi^{2}$ test. NS, not significant.

LN metastasis negative and positive tumors. Previously, we reported that GSTP1 hypermethylation correlates with LN metastasis [24]. Similarly in this study, only GSTP1 hypermethylation was found to be more frequent in the LN metastasis positive group than in the negative group. In both LN metastasis positive and negative groups, GSTP1 hypermethylation was found to be more common in ER-positive than in ER-negative tumors. Furthermore, the differences in methylation status of RASSF1A and CCND2 between the ER-positive and ER-negative groups can be recognized in early stages of cancer, such as the T1c or N0 stages. These findings suggest that ER expression may influence epigenetic changes in early stages of breast cancer.
HER2/neu is another important prognostic marker for breast cancer. HER2/neu gene over-expression is identified in $15 \%$ to $25 \%$ of invasive breast carcinomas, and is related to metastatic potential and poor survival $[35,46]$. In our study, HER2/ neu over-expression was identified in $27 \%$ of breast cancers, and was independent of ER status. A negative relation between ER status and HER2/neu over-expression has been documented by others $[9,38,39]$. One of the plausible explanations for the lack of difference found in the frequency of HER2/neu-positive tumors between the ER-negative and ERpositive groups is that patients included in the present study were relatively young (average age 51 years). According to Huang and coworkers [38], in women younger than 45 years the inverse association between ER and HER2/neu was not apparent. Of our sample population, 37\% of patients were under $\mathbf{4 5}$ years old, and this age distribution may explain why we could not detect an inverse relation between ER and HER2/neu status. Regarding gene methylation and HER2/neu status, Fiegl and colleagues [47] reported that methylation of CDH13, MYOD1, PGR, and HSD17B4 exhibited a positive association with HER2/neu expression. We demonstrated that APC, GSTP1, and RASSF1A are more frequently methylated in the HER2/neu over-expressed group. These findings indicate that there are epigenetic differences between HER2/ neu breast tumors, and logistic regression analysis showed that these differences are independent of ER status.

Figure 1

\section{RASSF1A}

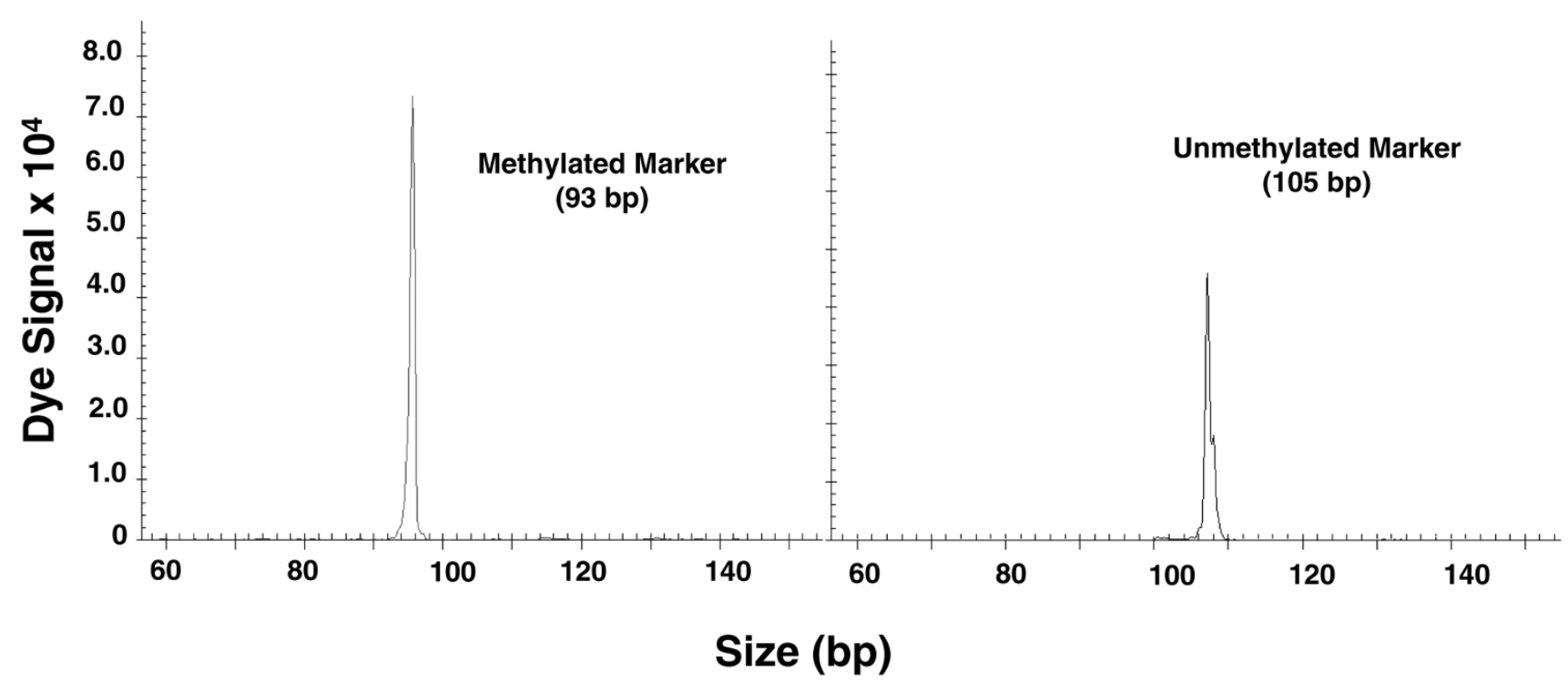

Methylated and unmethylated markers. Presented are representative methylation-specific PCR results of biomarker RASSF1A from a paraffinembedded archival breast tissue specimens, showing methylated and unmethylated markers. bp, base pairs. 
Table 8

Methylated primary ER-negative and ER-positive tumors: T1C and T2/T3 subgroups

\begin{tabular}{|c|c|c|c|c|c|c|}
\hline \multirow[b]{2}{*}{ Gene } & \multicolumn{3}{|l|}{$\mathrm{T} 1 \mathrm{c}(n=48)$} & \multicolumn{3}{|l|}{$\mathrm{T} 2 / \mathrm{T} 3(n=82)$} \\
\hline & ER negative $(n=24)$ & ER positive $(n=24)$ & $P$ value ${ }^{a}$ & ER negative $(n=41)$ & ER positive $(n=41)$ & $P$ value ${ }^{a}$ \\
\hline RASSF1A & $13(54 \%)$ & $21(88 \%)$ & 0.011 & $23(56 \%)$ & 39 (95\%) & $<0.0001$ \\
\hline CCND2 & $10(42 \%)$ & $20(83 \%)$ & 0.0029 & $16(39 \%)$ & $25(61 \%)$ & 0.0468 \\
\hline GSTP1 & $3(13 \%)$ & $6(25 \%)$ & NS & $1(2 \%)$ & $13(32 \%)$ & 0.0004 \\
\hline TWIST & $6(25 \%)$ & $12(50 \%)$ & NS & $11(27 \%)$ & $20(49 \%)$ & 0.0404 \\
\hline$A P C$ & $9(38 \%)$ & $8(33 \%)$ & NS & $11(27 \%)$ & $23(56 \%)$ & 0.0071 \\
\hline
\end{tabular}

${ }^{a} \chi^{2}$ test or Fisher's exact test was used appropriately. ER, estrogen receptor; NS, not significant.

Clinically, HER2/neu-negative, ER-negative, and PR-negative breast cancers are referred to as triple-negative breast cancers. About $85 \%$ of triple-negative breast tumors phenotypes are deemed to be basal-like subtypes, and they are associated with poor clinical outcome [48]. Because the progesterone receptor status of our samples was not well defined, we compared the methylation status of ER-negative and HER2/neunegative breast tumors (double-negative) with breast cancers expressing either ER or HER2/neu. Double-negative breast tumors exhibited frequent hypermethylation in APC, GSTP1, RASSF1A, and TWIST, revealing the presence of epigenetic differences between double-negative breast tumors and breast cancers expressing either HER2/neu or ER. Furthermore, both ER and HER2/neu status contributed independently to the difference in expression of APC, GSTP1, and RASSF1A. There is evidence that gene expression heterogeneity occurs in basal-like tumors of triple negatives; these subgroups are present with different pathology and clinical properties. Triple negative and ER and HER2/neu-positive status and gene expression levels of tumors may be quite heterogeneous in tumor populations, thus contributing to different subclassifications. Other additional biomarkers may be needed to subclassify phenotypes better [49,50].

Another interesting finding is the correlation of methylation status between the tumor-related genes. Methylation status of
RASSF1A, CCND2, GSTP1, TWIST, and APC, which was significantly higher in the ER-positive group, was correlated with the methylation status of two or more of the four other genes. Nonrandom distribution of methylation in tumor-related genes has previously been reported; Nass and coworkers [51] and $\mathrm{Li}$ and colleagues [45] found coincident methylation of CDH1 and ESR1, and Parrella and coworkers [52] reported that ESR1 promoter hypermethylation status correlates with those of $C D H 1, G S T P 1, C C N D 2$, and TRb1. Our findings revealed that occurrence of promoter region hypermethylation of RASSF1A, CCND2, GSPT1, TWIST, and APC are associated, whereas $\mathrm{CDH} 1$ methylation exhibited no correlation with methylation of those five genes (data not shown). This apparent nonrandom distribution of promoter hypermethylation of some genes suggests the existence of specific factors causing selective promoter region hypermethylation of tumorrelated genes.

\section{Conclusion}

In this study, we demonstrated - for the first time - that epigenetic differences between ER-positive and ER-negative breast tumors arise early in cancer development and persist during cancer progression. Furthermore, we reported epigenetic differences between HER2/neu-positive and HER2/neu-negative breast tumors, and between double-negative breast tumors and breast tumors expressing either HER2/neu or ER.

Table 9

Methylated primary ER-negative and ER-positive tumors: NO and N1/N2 subgroups

\begin{tabular}{lllllll}
\hline & No $(n=76)$ & \multicolumn{3}{c}{ N1/N2 $(n=54)$} \\
\cline { 2 - 6 } Genes & ER negative $(n=38)$ & ER positive $(n=38)$ & $P$ value $^{\mathrm{a}}$ & ER negative $(n=27)$ & ER positive $(n=27)^{*} P$ value $^{\mathrm{a}}$ \\
\hline RASSF1A & $18(47 \%)$ & $36(95 \%)$ & $<0.0001$ & $18(67 \%)$ & $24(89 \%)$ & 0.0495 \\
CCND2 & $16(42 \%)$ & $26(68 \%)$ & 0.021 & $10(37 \%)$ & $19(70 \%)$ & 0.014 \\
GSTP1 & $1(3 \%)$ & $7(18 \%)$ & 0.025 & $3(11 \%)$ & $12(44 \%)$ & 0.0062 \\
TWIST & $11(29 \%)$ & $17(45 \%)$ & NS & $6(22 \%)$ & $12(44 \%)$ & NS \\
APC & $11(29 \%)$ & $19(50 \%)$ & NS & $9(33 \%)$ & $12(4)$ &
\end{tabular}

${ }^{a} \chi^{2}$ test or Fisher's exact test was used appropriately. ER, estrogen receptor; NS, not significant. 
Table 10

Comparison of primary tumor gene methylation status relative to HER2/neu status

\begin{tabular}{|c|c|c|c|c|c|}
\hline \multirow[b]{2}{*}{ Gene } & \multicolumn{2}{|c|}{ HER2/neu negative $(n=78)$} & \multicolumn{2}{|c|}{ HER2/neu positive $(n=29)$} & \multirow[t]{2}{*}{$P$ value ${ }^{a}$} \\
\hline & $n$ & $\%$ & $n$ & $\%$ & \\
\hline RASSF1A & 55 & $71 \%$ & 27 & $93 \%$ & 0.007 \\
\hline CCND2 & 44 & $56 \%$ & 15 & $52 \%$ & NS \\
\hline GSTP1 & 10 & $13 \%$ & 12 & $41 \%$ & 0.0019 \\
\hline TWIST & 29 & $37 \%$ & 11 & $38 \%$ & NS \\
\hline$A P C$ & 26 & $33 \%$ & 17 & $59 \%$ & 0.0185 \\
\hline NES1 & 22 & $28 \%$ & 7 & $24 \%$ & NS \\
\hline$R A R \beta 2$ & 20 & $26 \%$ & 11 & $38 \%$ & NS \\
\hline $\mathrm{CDH} 1$ & 68 & $87 \%$ & 20 & $67 \%$ & 0.036 \\
\hline
\end{tabular}

${ }^{a} \chi^{2}$ test or Fisher's exact test was used appropriately. HER, human epidermal growth factor receptor; NS, not significant.

Taking advantage of potential reversibility of DNA methylation, epigenetic therapies directed against various cancers have been in development; 5-azacytidine, 5-aza-2'-deoxycytidines, procainamide, and hydralazine are promising agents. Investigators are attempting to combine epigenetic therapy with other standard therapies [2,53]. For breast cancer, one approach may to combine hormone therapy and antimethylation treatment. Integrated information regarding clinical factors influencing therapeutic principles and epigenetic features, such as promoter hypermethylation of tumor-related genes, will be important for combining epigenetics targeting drugs and standard chemotherapy.

\section{Competing interests}

The authors have submitted a patent application relating to the content of this manuscript.

\section{Authors' contributions}

ES and MS performed methylation assays for the studies. MSS was the biostatistician in the study. SLN performed assays and assembled the data. A-TV helped with assays. AEG performed the clinical review of the patients and reviewed the study design. DSNH was the principle investigator and designed and reviewed the study.

Table 11

Comparison of primary tumor gene methylation status relative to double-negative breast cancers versus cancers expressing either ER or HER2/neu

\begin{tabular}{llllll}
\hline Gene & \multicolumn{2}{l}{ Double negative $(n=37)$} & \multicolumn{2}{l}{ Either ER positive or HER2/neu positive $(n=70)$} & $P$ value $^{\mathrm{a}}$ \\
\cline { 2 - 5 } & $n$ & $\%$ & $n$ & $\%$ & $<0.0001$ \\
\hline RASSF1A & 18 & $47 \%$ & 64 & $91 \%$ & $\mathrm{NS}$ \\
CCND2 & 16 & $43 \%$ & 43 & $61 \%$ & $<0.0001$ \\
GSTP1 & 0 & $0 \%$ & 22 & $31 \%$ & 0.0031 \\
TWIST & 7 & $19 \%$ & 33 & $47 \%$ & 0.0035 \\
APC & 8 & $22 \%$ & 35 & $50 \%$ & $\mathrm{NS}$ \\
NES1 & 8 & $22 \%$ & 21 & $30 \%$ & $\mathrm{NS}$ \\
RAR 32 & 10 & $27 \%$ & 21 & $30 \%$ & $\mathrm{NS}$ \\
CDH1 & 33 & $89 \%$ & 55 & $79 \%$ & \\
\hline
\end{tabular}

${ }^{a} \chi^{2}$ test or Fisher's exact test was used appropriately. ER, estrogen receptor; NS, not significant; HER, human epidermal growth factor. 
Table 12

The relation between the methylated genes relative to methylation status

\begin{tabular}{lllll}
\hline Genes & TWIST & RASSF1A & CCND2 & APC \\
\hline GSTP1 & $<0.0001$ & 0.008 & 0.0006 & 0.0002 \\
TWIST & - & 0.047 & 0.003 & NS \\
RASSF1A & - & - & NS & 0.01 \\
CCND2 & - & - & - & NS \\
\hline
\end{tabular}

${ }^{a} \chi^{2}$ test. NS, not significant.

\section{Acknowledgements}

This study was funded by the Fashion Footwear Association of New York (FFANY), The Avon Foundation, The Leslie and Susan Gonda (Goldschmied) Foundation, and The Susan G. Komen Breast Cancer Foundation

\section{References}

1. Bae YK, Brown A, Garrett E, Bornman D, Fackler MJ, Sukumar S, Herman JG, Gabrielson E: Hypermethylation in histologically distinct classes of breast cancer. Clin Cancer Res 2004, 10:5998-6005.

2. Issa JP: DNA methylation as a therapeutic target in cancer. Clin Cancer Res 2007, 13:1634-1637.

3. Widschwendter M, Siegmund KD, Muller HM, Fiegl $\mathrm{H}$, Marth $\mathrm{C}$, Muller-Holzner E, Jones PA, Laird PW: Association of breast cancer DNA methylation profiles with hormone receptor status and response to tamoxifen. Cancer Res 2004, 64:3807-3813.

4. Kepple J, Henry-Tillman RS, Klimberg VS, Layeeque R, Siegel E, Westbrook K, Korourian S: The receptor expression pattern in ductal carcinoma in situ predicts recurrence. Am J Surg 2006, 192:68-71.

5. Duffy MJ: Estrogen receptors: role in breast cancer. Crit Rev Clin Lab Sci 2006, 43:325-347.

6. Gururaj AE, Rayala SK, Vadlamudi RK, Kumar R: Novel mechanisms of resistance to endocrine therapy: genomic and nongenomic considerations. Clin Cancer Res 2006, 12:1001s-1007s

7. Ma H, Bernstein L, Ross RK, Ursin G: Hormone-related risk factors for breast cancer in women under age 50 years by estrogen and progesterone receptor status: results from a casecontrol and a case-case comparison. Breast Cancer Res 2006, 8:R39.

8. Rusiecki JA, Holford TR, Zahm SH, Zheng T: Breast cancer risk factors according to joint estrogen receptor and progesterone receptor status. Cancer Detect Prev 2005, 29:419-426.

9. Schiff R, Massarweh SA, Shou J, Bharwani L, Arpino G, Rimawi M, Osborne CK: Advanced concepts in estrogen receptor biology and breast cancer endocrine resistance: implicated role of growth factor signaling and estrogen receptor coregulators. Cancer Chemother Pharmacol 2005, 56(suppl 1):10-20.

10. Colditz GA, Rosner BA, Chen WY, Holmes MD, Hankinson SE: Risk factors for breast cancer according to estrogen and progesterone receptor status. J Natl Cancer Inst 2004, 96:218-228.

11. Chu KC, Anderson WF: Rates for breast cancer characteristics by estrogen and progesterone receptor status in the major racial/ethnic groups. Breast Cancer Res Treat 2002, 74:199-211.

12. Fan $C$, Oh DS, Wessels $L$, Weigelt $B$, Nuyten $D S$, Nobel $A B$, van't Veer LJ, Perou CM: Concordance among gene-expressionbased predictors for breast cancer. N Engl J Med 2006, 355:560-569.

13. Perou CM, Sørlie T, Eisen MB, Rijn M van de, Jeffrey SS, Rees CA, Pollack JR, Ross DT, Johnsen H, Akslen LA, Fluge O, Pergamenschikov A, Williams C, Zhu SX, Lønning PE, Børresen-Dale AL,
Brown PO, Botstein D: Molecular portraits of human breast tumours. Nature 2000, 406:747-752.

14. Fenton SL, Dallol A, Agathanggelou A, Hesson L, Ahmed-Choudhury J, Baksh S, Sardet C, Dammann R, Minna JD, Downward J, Maher ER, Latif F: Identification of the E1A-regulated transcription factor p120 E4F as an interacting partner of the RASSF1A candidate tumor suppressor gene. Cancer Res 2004, 64:102-107.

15. Spugnardi M, Tommasi S, Dammann R, Pfeifer GP, Hoon DS: Epigenetic inactivation of RAS association domain family protein 1 (RASSF1A) in malignant cutaneous melanoma. Cancer Res 2003, 63:1639-1643.

16. Burbee DG, Forgacs E, Zöchbauer-Müller S, Shivakumar L, Fong K, Gao B, Randle D, Kondo M, Virmani A, Bader S, Sekido Y, Latif F, Milchgrub S, Toyooka S, Gazdar AF, Lerman MI, Zabarovsky E, White M, Minna JD: Epigenetic inactivation of RASSF1A in lung and breast cancers and malignant phenotype suppression. $J$ Natl Cancer Inst 2001, 93:691-699.

17. Lee MG, Kim HY, Byun DS, Lee SJ, Lee CH, Kim Jl, Chang SG Chi SG: Frequent epigenetic inactivation of RASSF1A in human bladder carcinoma. Cancer Res 2001, 61:6688-6692.

18. Agathanggelou A, Cooper WN, Latif F: Role of the Ras-association domain family 1 tumor suppressor gene in human cancers. Cancer Res 2005, 65:3497-3508.

19. Whang YM, Kim YH, Kim JS, Yoo YD: RASSF1A suppresses the c-Jun-NH2-kinase pathway and inhibits cell cycle progression Cancer Res 2005, 65:3682-3690.

20. Vos MD, Martinez A, Elam C, Dallol A, Taylor BJ, Latif F, Clark GJ: A role for the RASSF1A tumor suppressor in the regulation of tubulin polymerization and genomic stability. Cancer Res 2004, 64:4244-4250.

21. Evron E, Umbricht CB, Korz D, Raman V, Loeb DM, Niranjan B Buluwela L, Weitzman SA, Marks J, Sukumar S: Loss of cyclin D2 expression in the majority of breast cancers is associated with promoter hypermethylation. Cancer Res 2001, 61:2782-2787.

22. Padar A, Sathyanarayana UG, Suzuki M, Maruyama R, Hsieh JT, Frenkel EP, Minna JD, Gazdar AF: Inactivation of cyclin D2 gene in prostate cancers by aberrant promoter methylation. Clin Cancer Res 2003, 9:4730-4734.

23. Key TJ, Allen NE, Spencer EA, Travis RC: Nutrition and breast cancer. Breast 2003, 12:412-416.

24. Shinozaki M, Hoon DS, Giuliano AE, Hansen NM, Wang HJ, Turner $\mathrm{R}$, Taback B: Distinct hypermethylation profile of primary breast cancer is associated with sentinel lymph node metastasis. Clin Cancer Res 2005, 11:2156-2162.

25. Yang J, Mani SA, Donaher JL, Ramaswamy S, Itzykson RA, Come C, Savagner P, Gitelman I, Richardson A, Weinberg RA: Twist, a master regulator of morphogenesis, plays an essential role in tumor metastasis. Cell 2004, 117:927-939.

26. Fackler MJ, McVeigh M, Evron E, Garrett E, Mehrotra J, Polyak K, Sukumar S, Argani P: DNA methylation of RASSF1A, HIN-1, RAR-beta, Cyclin D2 and Twist in in situ and invasive lobular breast carcinoma. Int J Cancer 2003, 107:970-975.

27. Jin Z, Tamura G, Tsuchiya T, Sakata K, Kashiwaba M, Osakabe M, Motoyama T: Adenomatous polyposis coli (APC) gene promoter hypermethylation in primary breast cancers. $\mathrm{Br} J$ Cancer 2001, 85:69-73.

28. Virmani AK, Rathi A, Sathyanarayana UG, Padar A, Huang CX, Cunnigham HT, Farinas AJ, Milchgrub S, Euhus DM, Gilcrease M, Herman J, Minna JD, Gazdar AF: Aberrant methylation of the adenomatous polyposis coli (APC) gene promoter $1 \mathrm{~A}$ in breast and lung carcinomas. Clin Cancer Res 2001, 7:1998-2004.

29. Sarrio D, Moreno-Bueno G, Hardisson D, Sanchez-Estevez C, Guo M, Herman JG, Gamallo C, Esteller M, Palacios J: Epigenetic and genetic alterations of APC and CDH1 genes in lobular breast cancer: relationships with abnormal E-cadherin and catenin expression and microsatellite instability. Int J Cancer 2003, 106:208-215.

30. Liu XL, Wazer DE, Watanabe K, Band V: Identification of a novel serine protease-like gene, the expression of which is downregulated during breast cancer progression. Cancer Res 1996, 56:3371-3379.

31. Goyal J, Smith KM, Cowan JM, Wazer DE, Lee SW, Band V: The role for NES1 serine protease as a novel tumor suppressor. Cancer Res 1998, 58:4782-4786. 
32. Mehrotra J, Vali M, McVeigh M, Kominsky SL, Fackler MJ, LahtiDomenici J, Polyak K, Sacchi N, Garrett-Mayer E, Argani P, Sukumar S: Very high frequency of hypermethylated genes in breast cancer metastasis to the bone, brain, and lung. Clin Cancer Res 2004, 10:3104-3109.

33. Zanardi S, Serrano D, Argusti A, Barile M, Puntoni M, Decensi A: Clinical trials with retinoids for breast cancer chemoprevention. Endocr Relat Cancer 2006, 13:51-68.

34. Mahler-Araujo B, Savage K, Parry S, Reis-Filho JS: Reduction of E-cadherin expression is associated with non-lobular breast carcinomas of basal-like and triple negative phenotype. J Clin Pathol 2008, 61:615-620.

35. Francis G, Beadle G, Thomas S, Mengersen K, Stein S: Evaluation of oestrogen and progesterone receptor status in HER-2 positive breast carcinomas and correlation with outcome. Pathology 2006, 38:391-398.

36. Ross JS, Fletcher JA: The HER-2/neu oncogene in breast cancer: prognostic factor, predictive factor, and target for therapy. Stem Cells 1998, 16:413-428.

37. Wright C, Nicholson S, Angus B, Sainsbury JR, Farndon J, Cairns J, Harris AL, Horne $\mathrm{CH}$ : Relationship between c-erbB-2 protein product expression and response to endocrine therapy in advanced breast cancer. Br J Cancer 1992, 65:118-121.

38. Huang $\mathrm{HJ}$, Neven $\mathrm{P}$, Drijkoningen $\mathrm{M}$, Paridaens $\mathrm{R}$, Wildiers $\mathrm{H}$, Van Limbergen E, Berteloot P, Amant F, Vergote I, Christiaens MR: Hormone receptors do not predict the HER2/neu status in all age groups of women with an operable breast cancer. Ann Oncol 2005, 16:1755-1761.

39. Balsari A, Casalini P, Tagliabue E, Greco M, Pilotti S, Agresti R, Giovanazzi R, Alasio L, Rumio C, Cascinelli N, Colnaghi MI, Ménard S: Fluctuation of HER2 expression in breast carcinomas during the menstrual cycle. Am J Pathol 1999, 155:1543-1547.

40. Read LD, Keith D Jr, Slamon DJ, Katzenellenbogen BS: Hormonal modulation of HER-2/neu protooncogene messenger ribonucleic acid and $\mathrm{p} 185$ protein expression in human breast cancer cell lines. Cancer Res 1990, 50:3947-3951.

41. Greene FL, Page DL, Fleming ID, Fritz A, Balch CM, Haller DG, Morrow M: Cancer Staging Manual 6th edition. New York: Springer; 2002.

42. D'Andrea MR, Limiti MR, Bari M, Zambenedetti P, Montagutti A, Ricci F, Pappagallo GL, Sartori D, Vinante O, Mingazzini PL: Correlation between genetic and biological aspects in primary non-metastatic breast cancers and corresponding synchronous axillary lymph node metastasis. Breast Cancer Res Treat 2007, 101:279-284.

43. Giacinti L, Claudio PP, Lopez M, Giordano A: Epigenetic information and estrogen receptor alpha expression in breast cancer. Oncologist 2006, 11:1-8.

44. Leu YW, Yan PS, Fan M, Jin VX, Liu JC, Curran EM, Welshons WV, Wei SH, Davuluri RV, Plass C, Nephew KP, Huang TH: Loss of estrogen receptor signaling triggers epigenetic silencing of downstream targets in breast cancer. Cancer Res 2004, 64:8184-8192.

45. Li S, Rong M, lacopetta B: DNA hypermethylation in breast cancer and its association with clinicopathological features. Cancer Lett 2006, 237:272-280.

46. Slamon DJ, Godolphin W, Jones LA, Holt JA, Wong SG, Keith DE, Levin WJ, Stuart SG, Udove J, Ullrich A, et al:: Studies of the HER-2/neu proto-oncogene in human breast and ovarian cancer. Science 1989, 244:707-712.

47. Fiegl $\mathrm{H}$, Millinger S, Goebel G, Muller-Holzner E, Marth $\mathrm{C}$, Laird PW, Widschwendter M: Breast cancer DNA methylation profiles in cancer cells and tumor stroma: association with HER$2 /$ neu status in primary breast cancer. Cancer Res 2006, 66:29-33.

48. Bauer KR, Brown M, Cress RD, Parise CA, Caggiano V: Descriptive analysis of estrogen receptor (ER)-negative, progesterone receptor (PR)-negative, and HER2-negative invasive breast cancer, the so-called triple-negative phenotype: a populationbased study from the California cancer Registry. Cancer 2007, 109:1721-1728.

49. Cheang MC Voduc D, Bajdik C, Leung S, McKinney S, Chia SK, Perou CM, Nielsen TO: Basal-like breast cancer defined by five biomarkers has superior prognostic value than triple-negative phenotype. Clin Cancer Res 2008, 14:1368-1376.
50. Kreike B, van Kouwenhove $M$, Horlings $H$, Weigelt $B$, Peterse $H$, Bartelink $\mathrm{H}$, Vijver MJ van de: Gene expression profiling and histopathological characterization of triple-negative/basal-like breast carcinomas. Breast Cancer Res 2007, 9:R65.

51. Nass SJ, Herman JG, Gabrielson E, Iversen PW, Parl FF, Davidson $\mathrm{NE}$, Graff JR: Aberrant methylation of the estrogen receptor and $\mathrm{E}$-cadherin 5' $^{\prime} \mathrm{CpG}$ islands increases with malignant progression in human breast cancer. Cancer Res 2000, 60:4346-4348.

52. Parrella $P$, Poeta ML, Gallo AP, Prencipe M, Scintu M, Apicella A, Rossiello R, Liguoro G, Seripa D, Gravina C, Rabitti C, Rinaldi M, Nicol T, Tommasi S, Paradiso A, Schittulli F, Altomare V, Fazio VM: Nonrandom distribution of aberrant promoter methylation of cancer-related genes in sporadic breast tumors. Clin Cancer Res 2004, 10:5349-5354.

53. Yoo CB, Jones PA: Epigenetic therapy of cancer: past, present and future. Nat Rev Drug Discov 2006, 5:37-50. 